\title{
Mixed Mammary Carcinosarcoma in Domesticated Asian Palm Civet (Paradoxurus hermaphroditus)
}

\author{
Yos Adi Prakoso $^{1}$, Ratna Widyawati ${ }^{1}$, Roeswandono Wirjaatmadja ${ }^{1}$, Ady Kurnianto ${ }^{1}$ and Kurniasih $^{2}$ \\ ${ }^{I}$ Faculty of Veterinary Medicine, University of Wijaya Kusuma Surabaya, 60225, East Java, Indonesia \\ ${ }^{2}$ Department of Pathology, Faculty of Veterinary Medicine, University of Gadjah Mada, 55281, Yogyakarta, Indonesia \\ *Corresponding author's Email: yos.vet.docter@gmail.com
}

\begin{abstract}
A female Asian palm civet (Paradoxurus hermaphroditus), three years old was carried for a medical checkup to Ruddy animal's clinic in Sidoarjo, East Java, Indonesia. The civet suffers enlargement of abdominal mammary glands, painless lump, asymmetric size (4.1 and $8.4 \mathrm{~cm}$ in diameter), and lacerated wound on the large one with severe haemorrhage. The unilateral mastectomy was conducted under anaesthesia to handles both haemorrhage and tumour mass. Following the surgery, the tumour mass was stored in $10 \%$ neutral buffer formalin for histopathology using Hematoxylin \& Eosin (H\&E) staining and immunohistochemistry against antibody, anti-CD4+ and CD8+, further, a blood sample collected before and after surgery (on days: $0,7,30$, and 60 ) for representing the healing progress. The chemotherapy was given using the combination of oral cyclophosphamide and intravenous injection of vincristine. According to laboratory results, the final diagnosis was mixed mammary carcinosarcoma with minimal expression of CD8+, notwithstanding, it showed the better prognosis after surgery and chemotherapy.
\end{abstract}

Key words: Asian palm civet, CD4+, CD8+, Mixed mammary carcinosarcoma, Therapy

\section{INTRODUCTION}

Mixed mammary carcinosarcoma is an uncommon type of neoplasm in the animals because of consist malignant of differentiated cells and aggressive behaviour (Nunes et al., 2019). It has a high vascularisation sustains the abnormal proliferative cells to receive nutrition ( $\mathrm{Gal}$ et al., 2008). Moreover, it raises the malnutrition of the host body as the compensatory effects of metastases (Al-Mansour et al., 2018). However, the blood vessels of a mixed mammary tumour arranged as the temporary duct with high fragility, with an incomplete layer, so that facilitate the haemorrhage emergence (Forster et al., 2017). That case frequently reported in the bitch ( $>4$ years old). The contraceptive therapy also associated with the prevalence of mammary carcinoma in zoo animals especially canids (Moresco et al., 2009). The further theory stated that the failure of cytotoxic T-cell generates the proliferation of mammary carcinoma (Wei et al., 2008). Even though, the gene factor also contributes (Goebel and Merner, 2017).

In the clinic, a simple method to analyse and diagnose the mammary tumours in both human and animal is a cytological examination. However, this procedure is not satisfactory in canids because of the complex morphology of cells mammary tumours (Dolka et al., 2018). The histopathology and immunohistochemistry are known to be sufficient to analyse cells morphology and glycoprotein markers on the canine mammary tumours (Carvalho et al., 2016). The correct diagnoses facilitate the clinicians to provide precision therapy. Commonly, the surgical procedure is the principal treatment for mammary tumours. Mastectomy and chemotherapy are suggested to increase host survival rates (Dias et al., 2016). Gemcitabine, cyclophosphamide, vincristine, carboplatin and other anticancer drugs were demonstrated in the previous study (Karayannopoulou and Lafioniatis, 2016).

Among Indonesian civet, the mixed mammary carcinosarcoma hasn't reported due to the civet in Indonesia domesticated as the cultivation animal (to produce fermented coffee beans) and pet animal recently. This case provided the first report regarding mixed mammary carcinosarcoma in the Asian palm civet and supported by laboratory examination results that describe metastases phenomenon and its prognosis of healing.

\section{CASE REPORT}

\section{Ethical approval}

This experiment was performed according to the all ethics and animal rights in Ruddy animal's clinic in Indonesia. 


\section{Anamnesis and clinical examination}

On July 21, 2018, a female Asian palm civet, three years old was carried for a medical checkup to Ruddy animal's clinic in Sidoarjo, East Java, Indonesia. Based on the owner anamnesis, the mammary glands enlargement occurs within last two months ago and developing rapidly. The lacerated wound is caused by itself bites. The civet was fed a diet with chicken's head, raw meat, dry cat food and bananas. The drinks were given using the mineral water ad libitum and milk once a day at night. The owner reported that the civet routinely injected using the progestin contraceptive without a clear understanding of its side effects. The clinical appearance showed that civet suffers the enlargement of abdominal mammary glands in both left and right sides, asymmetrical size ( 4.1 and $8.4 \mathrm{~cm}$ in diameter), a painless lump, with a severe lacerated wound on the large one. The severe haemorrhage has also been identified. The structure of ribs and waistline indicates that the civet suffers chronic thinness. Another clinical finding showed the pale colour of the mucous membrane, however, with normal pulse, respiratory rates, and body temperature $\left(39.12^{\circ} \mathrm{C}\right)$.

\section{Premedication and anaesthesia}

The surgery is performed after the haematology analysis shows the standard value. Prior the anaesthesia, the premedication was conducted using the subcutaneous injection of atropine sulfate $(0.03 \mathrm{mg} / \mathrm{kg}$ of body weight; VTropin ${ }^{\circledR} ;$ Peru). Further, the dissociative anaesthetic was performed intramuscularly (Dugassa and Fromsa, 2018). It is utilising the combination of ketamine hydrochloride $(15 \mathrm{mg} / \mathrm{kg}$ of body weight; Ketamil@; Australia), and xylazine hydroxylate $(1.5 \mathrm{mg} / \mathrm{kg}$ of body weight; Xyla®; Holland). The abdominal hair surrounding the tumour mass was shaved using a hair clipper and disinfected using a $10 \%$ iodine tincture. Upon the civet under the anaesthesia, the sodium chloride inserted via the intravenous route using pediatric infuse set (25 drops/ minute; Infusion Set Child Gea®; Indonesia).

\section{Mastectomy}

Prior mastectomy, the ligation was performed on the blood vessels of the wound to prevent the blood loss. The unilateral mastectomy was conducted by elliptical skin incision surrounding the tumour mass, with a borderline within 2 $\mathrm{cm}$ from the central area. The blunt dissection was performed if the underlying muscle attached to the tumour mass. Dissection plane directed to the next healthy fascia to encounter the tumour invasion. Again, the haemorrhage is controlled by the ligation of the blood vessels. Warm saline was given to lavage the excision area. Closure of the surgical wound was conducted by the conventional technique to attach the skin with the fascia using absorbable suture (Catgut Chromic ${ }^{\circledR}$ 2/0; Bio SM; Belgium). Those procedures intend to decrease skin tension and space formation that can become the media for both exudate accumulation and bacterial colonisation. The last, simple interrupted suture is performed to link both two sides of the wound edge (Sadhasivan et al., 2017).

\section{Therapy}

On the wound, the $2 \%$ Aloe vera cream is applied topically. The surgical wound was then covered using the antibacterial gauze dressing (Sofra-tulle; Sanofi Aventis; Indonesia). The topical treatment and re-dressing is conducted every 24 hours (once a day). To prevent the secondary infection, the civet was treated twice a day for five days using oral amoxicillin $(10 \mathrm{mg} / \mathrm{kg}$ of body weight; Amoxicillin IF $500 \mathrm{mg}$; Indonesia). The chemotherapy was given using oral cyclophosphamide $\left(50 \mathrm{mg} / \mathrm{m}^{2}\right.$; Cyclophosphamide Tablet Kalbe®; Indonesia) for four days after mastectomy and repeated each week. It combined with vincristine $\left(0.1 \mathrm{mg} / \mathrm{m}^{2}\right.$; Vincristine $2 \mathrm{mg}$ Vial Kalbe®; Indonesia) that injected intravenously and repeated per seven days. The treatment is performed until two months (Karayannopoulou and Lafioniatis, 2016).

\section{Laboratory test}

The haematological profile is examined on day 0 before surgery, and re-examined on day 7, 30, and 60-post surgery as the monitoring data. Prior histopathology examination, the tissues is fixed in $10 \%$ Neutral Buffer Formalin (NBF) for 24 hours. The tissues was processed using the Hematoxylin and Eosin (H\&E) staining and Immunohistochemistry (IHC) against CD8+ and CD4+ antibody. All immuno-histopathological slides are analysed by two pathologists.

\section{RESULTS AND DISCUSSION}

Based on the histopathology examination, the epithelial cells highly differentiated forms the irregular papilla. The lumen covered by the mitotic epithelial cells that indicate the over differentiated (grade III) (Figure 1). On another part showed mineralisation (Figure 2) that is synthesised by the osteoblast in the mammary neoplasm tissue (Figure 3). The nuclear pleomorphism are marked by the variation of the nucleus size, more prominent nucleoli, and loss of basement membrane architecture (Figure 3). These mammary tumour is surrounded by fibrovascular tissue with high angiogenesis (Figure 4). Moreover, the adipocytes are identified in several parts and it is suspected transform into the adipose tissue (Figure 5). 
The differentiation of mammary neoplasm depresses and replaces the normal mammary tissue. Immunohistochemistry showed the minimal immune-expression of CD8+ (Figure 6) and surprisingly negative expression of CD4+. Those results indicate an inability of the immune system to inhibit the differentiation of the tumour cells during the tumorigenesis. Based on histopathology and immunohistochemistry the civet is diagnosed suffering mixed mammary carcinosarcoma.
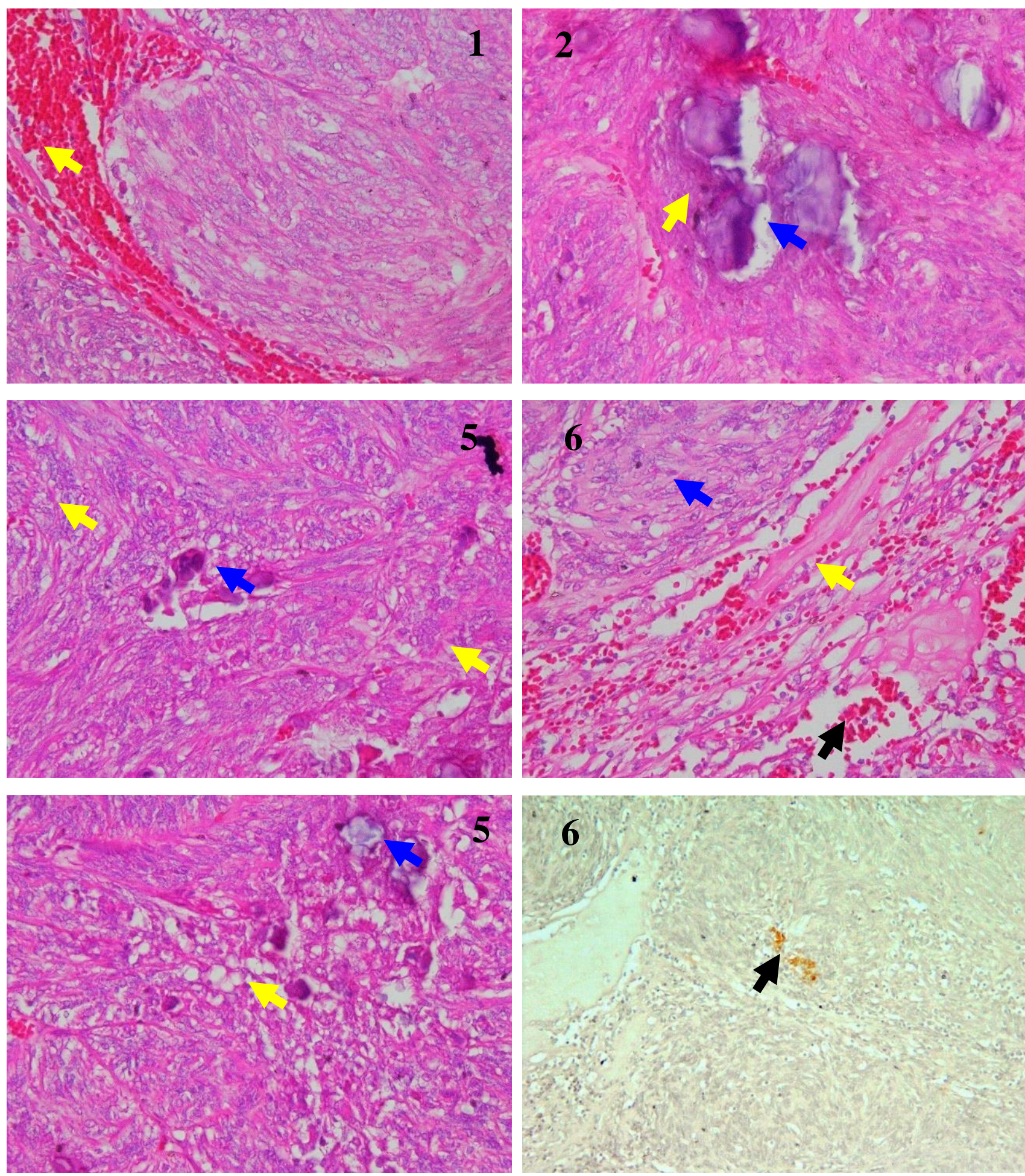

Figure 1. High differentiated of epithelial and the lumen not present (blue), predominant of vascularisation around the neoplasm (yellow) in mammary tissue of a female Asian palm civet. H\&E, 40x

Figure 2. Mineralisation on the central part of mammary tissue (blue) surrounded by the necrosis (yellow) in mammary tissue of a female Asian palm civet. H\&E, 40x

Figure 3. Osteoblast (blue) identified among the differentiated of epithelial cells, further the nucleus pleomorphism identified as the multiple nuclei (yellow) in mammary tissue of a female Asian palm civet. H\&E, 40x

Figure 4. High vascularisation (black) in the fibrovascular capsule area (yellow) of a tumour and basement membrane is unidentified (blue) in mammary tissue of a female Asian palm civet. H\&E, 40x

Figure 5. Adipocytes (yellow) found close to the mineralised area (blue) in mammary tissue of a female Asian palm civet. H\&E, 40x

Figure 6. Minimal expression of CD8+ (black) in mammary tissue of a female Asian palm civet. IHC anti-CD8+, DAB, 20x 
Mixed mammary carcinosarcoma is marked by the differentiated of one or both mesenchymal and epithelial cells (Campos et al., 2017). In this case, concluded as the malignant types because of its high index of mitosis, significantly appearance of the nucleoli pleomorphism, and the necrosis on the several parts of tumour tissue (Yoshimura et al., 2015). In human, the carcinosarcoma is growing fast even after surgery and, it is similar to ductal carcinoma (Accurso et al., 2016). The mixed mammary carcinosarcoma is not reported yet in the Viverridae, especially Asian palm civet. This disease suspected due to the utilisation of the progestin as the contraceptive therapy, even, the other factors such as dietary and geographic distribution maybe contributes. As the previous study reported that progesterone administration increase prevalence of the mammary carcinoma in wild animals (Tian et al., 2018). Malignant transformation of a benign tumour not only controlled by gene activity such as cyclin A and p53 but also is played by the cytotoxic T cells (CD8+) via the major histocompatibility complex class I (MHC I).

Cytotoxic T cells potentially control the dysplasia cells. In this case, the minimal expression of CD8+ indicates the failure of the immune system to inhibit tumorigenesis. Moreover, the absence of CD4+ shows the inhibition of healing mechanisms during the disease. CD4+ $\mathrm{T}$ cells is a dynamic cell that enhances the antitumor activity of $\mathrm{T}$ cell cytotoxic (Borst et al., 2018). Furthermore, the development of the myoepithelial cells in mixed mammary carcinosarcoma has not reported clearly (Singh et al., 2018). It is unclearly understood regarding the origin of carcinosarcoma cells and, further investigations are necessary.

The previous study explained the appropriate therapy against a mammary tumour is a mastectomy and it combines with the chemotherapy agents (Cassali et al., 2017). In this case, the unilateral mastectomy selected because of this procedure indicated for the multiple gland's tumours and easy to perform on skinny animals (Papazoglou et al., 2014). The surgical wound shows positive healing progress and it totally closures on seven days without exudation and secondary infection. It proves that topical combination of $2 \%$ aloe vera cream and antibacterial dressing gauze effective to promote wound healing. Moreover, the utilisation of cyclophosphamide and vincristine potentially inhibit the metastases during two months of the observed periods. Cyclophosphamide is the alkylating agent that able to bind the DNA and depress the DNA replication and mitosis (Prajapati et al., 2017), and vincristine binds the tubulin to inhibit cell's metaphase (Dong et al., 2016).

The combination of cyclophosphamide and vincristine generates good prognosis on the mixed mammary carcinosarcoma in civets without creating side effects. It is proved by the haematology results that tend to improve sequentially (Table 1). Further, the leucopenia was unidentified during the utilisation of cyclophosphamide and vincristine, and it is different from the previous study (Huyan et al., 2011). The other haematological results proved that plasma total protein, fibrinogen, and C-reactive protein in a stable condition, following by the total red blood cells and index of erythrocytes that improve concomitantly (Table 1). Those explain the positive response of the civets' physiology and its immune system after mastectomy and during the chemotherapy.

Table 1. Routine haematological examination results of Asian palm civet on day 0, 7, 30, and 60 (before and after mastectomy)

\begin{tabular}{lccccc}
\hline \multirow{2}{*}{ Parameters } & \multicolumn{3}{c}{ Haematology value (day) } & \multirow{2}{*}{ Reference value $^{* * *}$} \\
\cline { 2 - 4 } & $\mathbf{0}$ & $\mathbf{7}$ & $\mathbf{3 0}$ & $\mathbf{6 0}$ & $9.16-16.25$ \\
$\mathrm{RBC}\left(\times 10^{6} \mu \mathrm{L}\right)$ & 5.44 & 7.78 & 9.81 & 10.14 & $8.50-16.70$ \\
$\mathrm{Hb}(\mathrm{g} / \mathrm{dL})$ & 7.22 & 7.01 & 7.32 & 9.17 & $27.00-45.50$ \\
$\mathrm{PCV}(\%)$ & 25.11 & 25.8 & 27.41 & 28.02 & $24.00-31.00$ \\
$\mathrm{MCV}(\mathrm{fl})$ & 46.15 & 33.16 & 27.94 & 27.63 & $8.50-19.20$ \\
$\mathrm{MCH}(\mathrm{pg})$ & 13.27 & 9.01 & 7.46 & 9.04 & $27.60-36.80$ \\
$\mathrm{MCHC}(\%)$ & 28.75 & 27.17 & 26.70 & 32.72 & $4.40-18.56$ \\
$\mathrm{WBC}\left(\times 10^{3} \mu \mathrm{L}\right)$ & 6.83 & 7.25 & 8.44 & 7.99 & $1.05-8.26$ \\
$\mathrm{~L}\left(\times 10^{3} \mu \mathrm{L}\right)$ & 3.07 & 3.55 & 4.13 & 4.15 & $0.06-1.33$ \\
$\mathrm{M}\left(\times 10^{3} \mu \mathrm{L}\right)$ & 0.81 & 0.94 & 0.92 & 0.95 & $2.30-14.23$ \\
$\mathrm{~N}\left(\times 10^{3} \mu \mathrm{L}\right)$ & 1.63 & 1.81 & 2.27 & 2.07 & $0.01-0.22$ \\
$\mathrm{~B}\left(\times 10^{3} \mu \mathrm{L}\right)$ & 0.54 & 0.21 & 0.16 & 0.23 & $0.07-1.37$ \\
$\mathrm{E}\left(\times 10^{3} \mu \mathrm{L}\right)$ & 0.75 & 0.72 & 0.93 & 0.55 & $6.40-8.60$ \\
$\mathrm{PTP}(\mathrm{g} / \mathrm{dL})$ & 9.15 & 9.03 & 8.71 & 8.44 & - \\
$\mathrm{Fib}(\mathrm{g} / \mathrm{dL})$ & 1.23 & 1.41 & 1.93 & 1.21 & 11.25 \\
$\mathrm{CRP}(\mathrm{mg} / \mathrm{L})$ & 18.22 & 17.87 & 12.01 & -
\end{tabular}

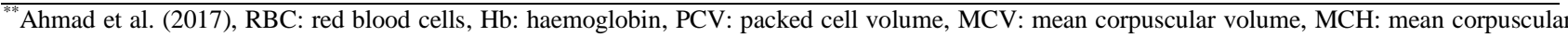
haemoglobin, MCHC: mean corpuscular haemoglobin concentration, WBC: white blood cells, L: lymphocytes, M: monocytes, N: neutrophil, B: basophil, E: eosinophil, PTP: plasma total protein, Fib: fibrinogen, CRP: C-reactive protein 


\section{CONCLUSION}

In conclusion, it was a unique and rare case of mixed mammary carcinosarcoma in Asian palm civet (Paradoxurus hermaphroditus). The mastectomy and the chemotherapy using a combination of cyclophosphamide and vincristine was the appropriate treatment in this case. The periodical observation on the haematological profile of the patients is a good biomarker identify the healing progress before and during the therapy.

\section{DECLARATIONS}

\section{Acknowledgements}

All the clinical procedures and laboratory examination fully funded by Zoans Animal Save and Care, Indonesia. Surabaya Musang Lovers is acknowledged for providing samples and permit the author to publish this case.

\section{Competing interests}

The authors declare that they have no conflict of interest.

\section{Consent to publish}

The authors guarantee that the contribution to the work has not been previously published elsewhere and that any person named as a co-author of this work is aware of the fact and has agreed to be so named.

\section{Author's contribution}

YAP and K participated during the mastectomy and histopathological analysis. RW, RW, and AK participated in haematology interpretation. All the authors participated in design, writing, revised, and reviewing the manuscript.

\section{REFERENCES}

Accurso A, Ciancia G, Corte GAD, Reale P, Accardo G, Salerno C, Bordoni D, Falco G and Rocco N (2016). A rare case of true carcinosarcoma of the breast. International Journal of Surgery Case Reports, 21: 125-128. Doi: https://doi.org/10.1016/j.jiscr.2016.03.004.

Ahmad AA, Jayarajah P, Han GWY, Yin SJOW and Rasedee A (2017). Haematology and serum biochemistry parameters for rescued common palm civets (Paradoxurus hermaphroditus) in different age group. The Journal of Veterinary Medicine Science, 79: 1134-1137. Doi: https://doi.org/10.1292\%2Fjvms.16-0082.

Al-Mansour MA, Kubba MAG, Al-Azreg SA and Dribika SA (2018). Comparative histopathology and immunohistochemistry of human and canine mammary tumors. Open Veterinary Journal, 8(3): 243-249. Doi:http://doi.org/10.4314/ovj.v8i3.3.

Borst J, Ahrends T, Babala N, Melief CJM and Kastenmuller W (2018). CD4+ T cell help in cancer immunology and immunotherapy. Nature Reviews Immunology, 18: 635-647. Doi:https://doi.org/10.1038/s41577-018-0044-0.

Campos CB, Lavalle GE, Ligorio SF, Monteiro LN, Amorim RL and Cassali GD (2017). Thalidomide treatment in a canine mammary gland carcinosarcoma presenting pulmonary metastasis. Advances in Animal and Veterinary Sciences, 5(3): 120-126. Doi:http://doi.org/10.14737/journal.aavs/2017/5.3.120.126.

Carvalho MI, Silva-Carvalho R, Pires I, Prada J, Bainchini R, Jensen-Jarolim E and Queiroga FL (2016). A comparative approach of tumor-associated inflammation on mammary cancer between humans and dogs. Biomed Research International, 2016(4917387): 1-12. Doi:https://doi.org/10.1155/2016/4917387.

Cassali GD, Damasceno KA, Bertagnolli AC, Estrela-Lima A, Lavalle GE, Di Santis GW, De Nardi AB, Fernandes CG, Cogliati B, Sobral R et al. (2017). Consensus regarding the diagnosis, prognosis and treatment of canine mammary tumors: benign mixed tumors, carcinomas in mixed tumors and carcinosarcomas. Brazilian Journal of Veterinary Pathology, 10(3):87-99. Doi:http://doi.org/10.24070/bjvp.1983-0246.v10i3p87-99.

Dias MLM, Andrade JLM, de Castro MB and Galera PD (2016). Survival analysis of female dogs with mammary tumors after mastectomy: epidemiological, clinical and morphological aspects. Pesquisa Veterinaria Brasileira, 36(3): 181-186. Doi:http://doi.org/10.1590/S0100-736X2016000300006.

Dolka I, Czopowicz M, Gruk-Jurka A, Wojtkowska A, Sapierzynski R and Jurka P (2018). Diagnostic efficacy of smear cytology and Robinson's cytological grading of canine mammary tumors with respect to histopathology, cytomorphometry, metastases and overall survival. PLoS ONE, 13(1): e0191595. Doi:https://doi.org/10.1371/journal.pone.0191595.

Dong X, Wang W, Qu H, Han D, Zheng J and Sun G (2016). Targeted delivery of doxorubicin and vincristine to lymph cancer: evaluation of novel nanostructured lipid carriers in vitro and in vivo. Drug Delivery, 23(4): 1374-1378. Doi:https://doi.org/10.3109/10717544.2015.1041580.

Dugassa J and Fromsa A (2018). Review on dissociative anaesthetics and compatible drug combinations in veterinary clinical practice. Veterinary Medicine Open Journal, 3(1): 21-30. Doi:http://doi.org/10.17140/VMOJ-3-129.

Forster JC, Harriss-Phillips WM, Douglass MJJ and Bezak E (2017). A review of development of tumor vasculature and its effects on the tumor microenvironment. Hypoxia, 5: 21-32. Doi:https://doi.org/10.2147\%2FHP.S133231.

Gal A, Catoi C, Rus I, Taulescu M, Bolfa P, Lakatos I and Baba AI (2008). The study of the vascularisation in bitch mammary tumours. Bulletin University of Agricultural Sciences and Veterinary Medicine, 65(1): 388-394. Doi:http://doi.org/10.15835/buasvmen-vm:65:1:1242. 
Goebel K and Merner ND (2017). A monograph proposing the use of canine mammary tumours as the model for the study of hereditary breast cancer susceptibility genes in humans. Veterinary Medicine and Science, 3(2): 51-62. Doi:https://doi.org/10.1002\%2Fvms3.61.

Huyan XH, Lin YP, Gao T, Chen RY and Fan YM (2011). Immunosuppressive effects of cyclophosphamide on white blood cells and lymphocytes subpopulations from peripheral blood of Balb/c mice. International Immunopharmacology, 11(9): 1293-1297. Doi:https://doi.org/10.1016/j.intimp.2011.04.011.

Karayannopoulou M and Lafioniatis S (2016). Recent advances on canine mammary cancer chemotherapy: a review of studies from 2000 to date. Revuede Medecine Veterinaire, 167(7-8): 192-200. Doi:https://www.revmedvet.com/artdes-us.php?id=16102.

Moresco A, Munson L and Gardner IA (2009). Naturally occurring and melengestrol acetate-associated reproductive tract lesions in zoo canids. Veterinary Pathology, 46(6): 1117-1128. Doi:https://doi.org/10.1354/vp.08-VP-0293-M-FL.

Tian JM, Ran B, Zhang CL, Yan DM and Li XH (2018). Estrogen and progesterone promote breast cancer cells proliferation by inducing cyclin G1 expression. Brazilian Journal of Medical Biological Research, 51(3): e5612. Doi:https://doi.org/10.1590\%2F1414-431X20175612.

Nunes FC, Damasceno KA, de Campos CB, Bertagnolli AC, Lavalle GE and Cassali GD (2019). Mixed tumors of canine mammary glands: evaluation of prognostic factors, treatment, and overall survival. Veterinary and Animal Science, 7: 100039. Doi:https://doi.org/10.1016/j.vas.2018.09.003.

Papazoglou LG, Basdani E, Rabidi S, Patsikas MN and Karayiannopoulou M (2014). Current surgical options for mammary tumor removal in dogs. Journal of Veterinary Science and Medicine, 2(1): 1-6. Doi:http://doi.org/10.13188/2325-4645.1000007.

Prajapati VB, Madhyastha S, Acharya R, Gopalaswamy V and Doddamani A (2017). Cyclophosphamide and doxorubicin induced melanonychia: a case report. Journal of Clinical and Diagnostic Research, 11(1): OD4-OD5. Doi:https://doi.org/10.7860/JCDR/2017/23041.9216.

Sadhasivan SBM, Shafiuzama M, Shammi M, Rao SVS, Souza NJD, Senthilnayagam H, George RS and Prabhakar PM (2017). Studies of reconstruction of large skin defects following mammary tumor excision in dogs. Veterinary World, 10(12): 15211528. Doi:https://doi.org/10.14202\%2Fvetworld.2017.1521-1528.

Singh GK, Singh P and Bhowmik KT (2018). Carcinosarcoma (metaplastic carcinoma) breast: a rare and aggressive primary - report of two cases with review of literature. Indian Journal of Medical and Pediatric Oncology, 39(3): 400-404. Doi:http://doi.org/10.4103/ijmpo.ijmpo_27_17.

Wei S, Shreiner AB, Takeshita N, Chen L, Zou W and Chang AE (2008). Tumor-induced immune suppression of in vivo effector Tcell priming is mediated by the B7-H1/PD-1 axis and transforming growth factor beta. Cancer Research, 68: 5432-5438. Doi:https://doi.org/10.1158/0008-5472.CAN-07-6598.

Yoshimura H, Kimura-Tsukada N, Ono Y, Michishita M, Ohkusu-Tsukada K, Matsuda Y, Ishiwata T and Takahashi K (2015). Characterization of spontaneous mammary tumors in domestic Djungarian hamster (Phodopus sungorus). Veterinary Pathology, 52(6): 1227-1234. Doi:https://doi.org/10.1177\%2F0300985815583097. 